\title{
Neuropeptide Amidation in Drosophila: Separate Genes Encode the Two Enzymes Catalyzing Amidation
}

\author{
Aparna S. Kolhekar, ${ }^{1}$ Marie S. Roberts, ${ }^{2}$ Ning Jiang, ${ }^{2}$ Richard C. Johnson, ${ }^{1}$ Richard E. Mains, ${ }^{1}$ \\ Betty A. Eipper, ${ }^{1}$ and Paul H. Taghert ${ }^{2}$ \\ ${ }^{1}$ Departments of Neuroscience and Physiology, The Johns Hopkins University School of Medicine, Baltimore, \\ Maryland 21205, and 2Department of Anatomy and Neurobiology, Washington University Medical School, St. Louis, \\ Missouri 63110
}

In vertebrates, the two-step peptide $\alpha$-amidation reaction is catalyzed sequentially by two enzymatic activities contained within one bifunctional enzyme called PAM (peptidylglycine $\alpha$-amidating mono-oxygenase). Drosophila head extracts contained both of these PAM-related enzyme activities: a monooxygenase (PHM) and a lyase (PAL). However, no bifunctional PAM protein was detected. We identified cDNAs encoding an active mono-oxygenase that is highly homologous to mammalian PHM. PHM-like immunoreactivity was found within diverse larval tissues, including the CNS, endocrine glands, and gut epithelium. Northern and Western blot analyses demonstrate RNA and protein species corresponding to the cloned PHM, but not to a bifunctional PAM, leading us to predict the existence of separate PHM and PAL genes in Drosophila. The Drosophila PHM gene displays an organization of exons that is highly similar to the PHM-encoding portion of the rat PAM gene. Genetic analysis was consistent with the prediction of separate $P H M$ and $P A L$ gene functions in Drosophila: a $P$ element insertion line containing a transposon within the PHM transcription unit displayed strikingly lower PHM enzyme levels, whereas PAL levels were increased slightly. The lethal phenotype displayed by the $A P H M P$ element insertion indicates a widespread essential function. Reversion analysis indicated that the lethality associated with the insertion chromosome likely is attributable to the $\mathrm{P}$ element insertion. These combined data indicate a fundamental evolutionary divergence in the genes coding for critical neurotransmitter biosynthetic enzymes: in Drosophila, the two enzyme activities of PAM are encoded by separate genes.

Key words: neuropeptide biosynthesis; Drosophila; $\alpha$-amidation; PAM; PHM; genetics; $P$ element
Neuropeptides are produced by a series of enzymatic steps that sequentially cleave and further modify larger precursor molecules (for review, see Sossin et al., 1989; Rouille et al., 1995; Seidah, 1995). Several of the enzymes that mediate these steps have been identified (Roebroek et al., 1991; Eipper et al., 1993; Lindberg and Zhou, 1995; Rouille et al., 1995). A significant modification is the enzymatic transformation of the $\mathrm{COOH}$-terminus in many biosynthetic peptide intermediates from a glycine to an $\alpha$-amide; this modification frequently is required for the biological activity of the peptides (for review, see Eipper et al., 1992). Amidation occurs on approximately one-half of the known bioactive neuropeptides, and secretory peptides are nearly the exclusive substrates for $\alpha$-amidation. Amidation of peptides first can be detected in the trans-Golgi network and is one of the final steps in

Received Aug. 15, 1996; revised Nov. 5, 1996; accepted Dec. 2, 1996.

This work was supported by grants from National Institutes of Health (DK-32949 to B.A.E. and NS-21749 to P.H.T.) and by the McDonnell Center for Cellular and Molecular Neurobiology (to P.H.T.). We thank Anneliese Schaefer for performing the chromosome localization by in situ hybridization described in this paper. We thank Mike Nonet for help with fluoresence microscopy and Suzy Renn for help with photography. We thank Alex Kolodkin and Mike Horner for advice with PCR. We thank Phil Beachy and Erich Buchner for gifts of cDNA libraries, Carl Thummel for sending P1 stocks, and Todd Laverty, Berkeley Drosophila Genome Project (BDGP), and the Bloomington Stock Center for sending Drosophila stocks. We thank Linda Hall for discussing unpublished information about the 60A region. We are grateful to Mike Nonet and Ross Cagan for comments on a draft of this manuscript. Also, we thank the members of our laboratories for many helpful conversations and suggestions.

Correspondence should be addressed to Dr. Paul H. Taghert, Department of Anatomy and Neurobiology, Box 8108, Washington University Medical School, 660 South Euclid Avenue, St. Louis, MO 63110.

Copyright (C) 1997 Society for Neuroscience $0270-6474 / 97 / 171363-14 \$ 05.00 / 0$ neuropeptide biosynthesis. It is, therefore, prevalent and functionally important to a broad class of neuropeptide messengers. In addition, $\alpha$-amidation may be a rate-limiting step in the production of neuropeptides: glycine-extended forms of several neuropeptides exist in vivo in measurable quantities (for review, see Eipper et al., 1992, 1993). Amidation may, therefore, represent a point of regulation for neuropeptide biosynthesis.

In animals as diverse as hydra, Drosophila, and man, the precursors of amidated neuropeptides contain a Gly residue immediately C terminal to the site of amidation (Nambu et al., 1988; Nichols et al., 1988; Schneider and Taghert, 1988; Nassel, 1994; Grimmelikhuijzen and Westfall, 1995). Peptide $\alpha$-amidation is a two-step reaction: first, the glycine-extended peptide substrate is hydroxylated by peptidylglycine- $\alpha$-hydroxylating mono-oxygenase (PHM) (Perkins et al., 1990; Tajima et al., 1990). Cleavage of the intermediate to form the final $\alpha$-amidated peptide product (and glyoxylate) is catalyzed by a second enzyme, peptidyl $\alpha$-hydroxyglycine- $\alpha$-amidating lyase (PAL) (Eipper et al., 1991; Katopodis et al., 1991). PHM and PAL are cosynthesized as adjacent domains of the bifunctional peptidylglycine- $\alpha$-amidating mono-oxygenase (PAM) precursor (see Fig. 1). In the rat, human, bovine, and frog, the $P A M$ gene produces an array of soluble and membrane-associated proteins as a result of differential RNA splicing and protein modification (Ouafik et al., 1992). PHM shares significant sequence homology with dopamine $\beta$-monooxygenase (DBM), a key enzyme in catecholamine production (Southan and Kruse, 1989). The Drosophila DBM homolog, tyramine $\beta$-hydroxylase (TBH), recently was cloned and studied ge- 


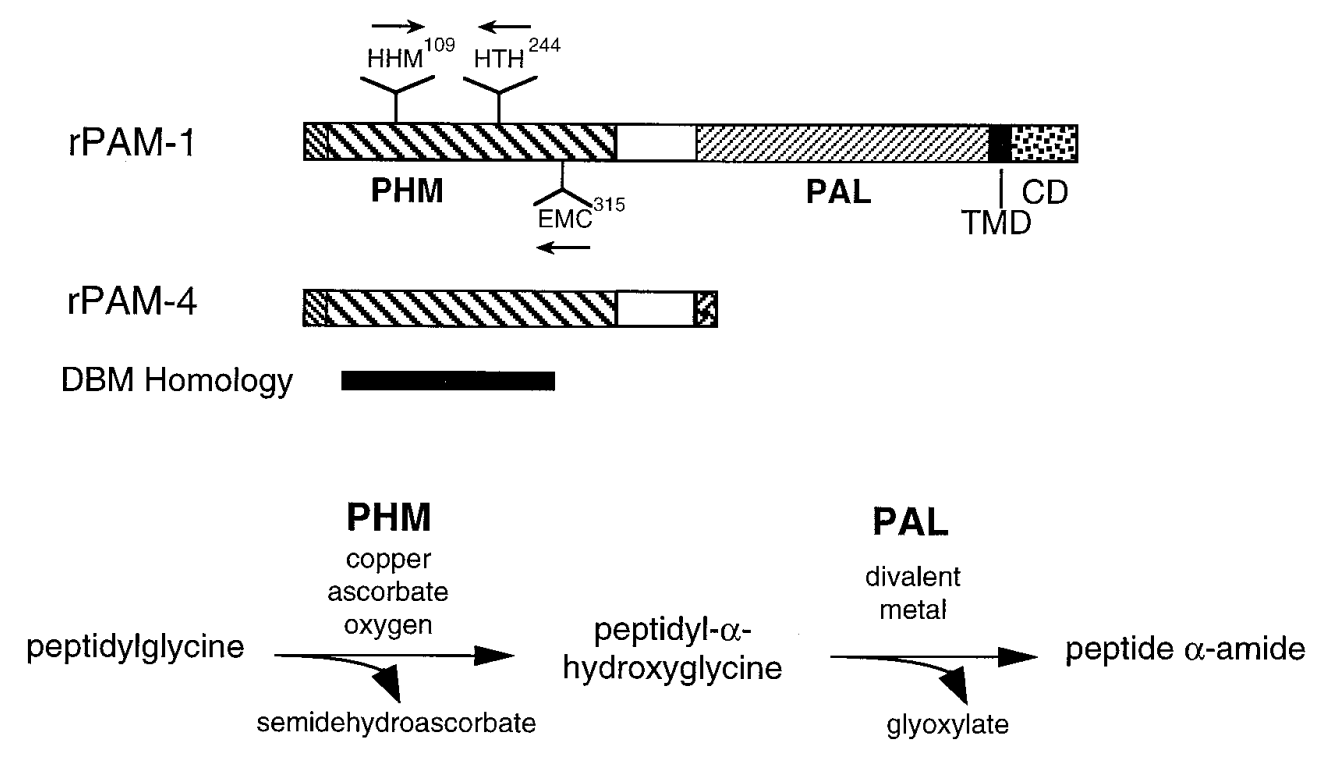

Figure 1. Structure and function of vertebrate PAM proteins. Bifunctional rat, integral membrane PAM $(P A M-1)$, and soluble monofunctional PHM (PAM-4) are shown, with the region homologous to dopamine $\beta$-mono-oxygenase marked (filled box). The functional domains are indicated: $P H M$, mono-oxygenase; $P A L$, lyase; $T M D$, transmembrane domain; $C D$, COOH-terminal cytoplasmic domain. The catalytically important conserved Histidine clusters used to design the PCR primers are indicated also. The catalytic requirements and the reactions catalyzed by PHM and PAL are shown at the bottom.

netically (Monastirioti et al., 1996). It is absolutely required for the production of the transmitter octopamine and mutates to display a female-sterile phenotype. DBM and $\mathrm{TBH}$ are both monofunctional enzymes and do not include a region homologous to PAL.

We have turned to Drosophila to use genetics to define PAM gene functions and regulation in vivo. Neuropeptides are important signaling molecules in insects, and $\alpha$-amidated neuropeptides are as prevalent in insects as they are in vertebrates. More than $90 \%$ of the reported insect neuropeptide sequences (from both peptide and DNA sequence analysis) contain or predict amidated $\mathrm{C}$ termini. Several amidated peptides have been purified from Drosophila (Nambu et al., 1988; Schaffer et al., 1990; Nichols, $1992 \mathrm{a}, \mathrm{b})$; the presence of many other amidated peptides has been deduced from the structure and expression of several Drosophila neuropeptide genes (Nichols et al., 1988; Schneider and Taghert, 1988; Taghert and Schneider, 1990; Veenstra, 1994). Although we found that Drosophila contains both PHM and PAL enzyme activities, we made the unexpected finding that this insect contains separate $P H M$ and $P A L$ genes. We report the structure and expression of the $d P H M$ gene and properties of expressed dPHM protein. We use this information to initiate a molecular genetic analysis of neuropeptide biosynthesis by demonstrating a lethal phenotype associated with a $\mathrm{P}$ element insertion that disrupts the dPHM gene.

\section{MATERIALS AND METHODS}

Molecular biology and Drosophila techniques. Standard molecular biology and Drosophila laboratory techniques were performed according to Sambrook et al. (1989) and Ashburner (1989).

Fly strains. Deficiency stocks [Df(2R)or-BR11, Df(2R)or-BR6, $\operatorname{Df}(2 \mathrm{R}) \mathrm{G} 10-7-5, \mathrm{Df}(2 \mathrm{R})$ bw-S46, $\mathrm{Df}(2 \mathrm{R})$ egl2, and $\mathrm{Df}(2 \mathrm{R}) \mathrm{Px} 1]$ were obtained from the Bloomington Stock Center. P element insertion lines were obtained from the Bloomington Stock Center [PZl(2)00628, $\left.\mathrm{PZl}(2) 02970, \mathrm{PZl}(2) 05006, \mathrm{PZl}(2) \mathrm{ken}[1], \mathrm{TE}\left(\mathrm{w}^{+}\right) 47\right]$ and from the Berkeley Drosophila Genome Project [1(2)06003, 1(2)09201, 1(2)01015, 1(2)04209, 1(2)04405, 1(2)04201, 1(2)07623, 1(2)03101, 1(2)k13409].

Tissue extraction and enzyme assays. Drosophila heads were homogenized and extracted with $20 \mathrm{~mm}$ Na TES, pH 7.4 and $10 \mathrm{~mm}$ mannitol in the presence of protease inhibitors (Husten and Eipper, 1991; Kolhekar et al., 1997). Insoluble pellets were resuspended in the above mixture with the addition of $1.0 \%$ Triton X-100. The soluble and detergent-extracted proteins were fractionated on a Superose 12 column, and the fractions were assayed for PHM and PAL as described by Husten and Eipper (1991).

RNA extraction and RT-PCR analysis. Pelleted cells from a dense $20 \mathrm{ml}$ culture of shibere (shi) cells were extracted into RNAStat60 (Tel-Test B). Reverse transcription was performed at $42^{\circ} \mathrm{C}$ using $2 \mu \mathrm{g}$ of total RNA, AMV reverse transcriptase (Promega, Madison, WI), and a degenerate PHM/DBM antisense primer (rPAM 1244-1231) [5'-NNRCACATYTCNTC-3']. PCR amplification was performed (35 cycles) using Taq polymerase (2.5 units; Boehringer Mannheim, Indianapolis, IN), $2 \mu \mathrm{l}$ of the reverse transcription, and degenerate sense [rPAM(607-624)] and antisense [rPAM(1037-1021)] primers: [5'-GGGAATTCGAYACTGYNCAYCAYATG-3', (EcoRI site underlined)] and [5'-GGTCTAGACCTAANTGRTGNGTRTG-3' (XbaI site underlined)], respectively. Denaturation was performed at $94^{\circ} \mathrm{C}$ for $1 \mathrm{~min}$ with annealing at $55^{\circ} \mathrm{C}$ for $2 \mathrm{~min}$ and extension at $72^{\circ} \mathrm{C}$ for $3 \mathrm{~min}$. Adult head RNA was extracted with RNAzol (Bio-Tek, Burlingame, CA) after homogenization. $\operatorname{Poly}(\mathrm{A})^{+}$RNA was selected with the oligotex mRNA kit (Qiagen, Hilden, Germany). RNAs were fractionated with formaldehyde-agarose gels and blotted to Nytran (Schleicher \& Schuell, Keene, NH) according to the manufacturer's recommendations.

Antibody production and purification. The $d P H M$ cDNA 1 was cloned into the pET-11 (Novagen, Madison, WI) expression vector and expressed in BL21 (DE3) bacteria, which were induced for $3 \mathrm{hr}$ with $0.4 \mathrm{~mm}$ IPTG. Recombinant dPHM protein was size-fractionated on a column of Bio-Gel A-0.5m (Bio-Rad, Richmond, CA) in 50 mM Na-HEPES, pH 7.4, containing $0.05 \%$ SDS and used to immunize rabbits. Immune serum was affinity-purified using an Affigel 15 matrix (Bio-Rad) according to the manufacturer's recommendation. Eluted antibodies were stored in PBS containing $0.8 \mathrm{mg} / \mathrm{ml}$ BSA and $0.1 \%$ sodium azide.

Immunocytochemistry. Larval CNS were dissected in saline and fixed overnight at $4{ }^{\circ} \mathrm{C}$ in a solution containing one part Bouin's and four parts $4 \%$ paraformaldehyde (in PBS, $\mathrm{pH}$ 7.4). For double-labeling experiments (to stain both lacZ- and PHM-like immunoreactivities), the fixative was one part Bouin's and nine parts $4 \%$ paraformaldehyde. After washes in PBS containing $0.3 \%$ Triton $\mathrm{X}-100$, tissues were stained in whole mount according to general procedures that were previously described (Taghert and Schneider, 1990). Anti- $\beta$ galactosidase monoclonal antibodies were purchased from Promega and used at a 1:1000 dilution. Cy-3-, Texas Red-, FITC-, and HRP-conjugated antibodies were purchased from Jackson Laboratories (Bar Harbor, ME) and were used at a 1:200 dilution.

Western blot analysis. Proteins fractionated by Superose 12 column chromatography (see above) were studied further by acrylamide gel electrophoresis and Western blot analysis. Proteins were transferred to Immobilon P membrane (Millipore, Bedford, MA); signals were developed using HRP-conjugated anti-rabbit antibodies and chemiluminescence techniques according to the manufacturer's recommendations (Amersham, Arlington Heights, IL) (Eipper et al., 1995).

Chromosome squashes and hybridization. Approximately $1 \mu \mathrm{g}$ of M7 phage DNA was biotin-labeled using the Bionick kit (Amersham) accord- 
ing to the manufacturer's recommendations. Hybridization was followed by use of the Detek-Hrp detection system (Enzo Diagnostics).

Microscopy and photography. Preparations were examined at 200$630 \times$, using Nomarski optics on a Zeiss Axioplan microscope, and photographed with Ektachrome 400 or Kodachrome 64 film. Fluorescent preparations were examined on a Max Olympus microscope, and images were captured using an MTI Sit camera and NIH image software. Images were colorized and assembled in Adobe Photoshop.

Inverse PCR. Genomic DNA from P element stocks was prepared and digested with either HinP1 or Sau3AI; these enzymes cut at defined sites within the $\mathrm{P}$ element and at unknown sites within the genomic DNA flanking each insertion site. After phenol/chloroform extraction and precipitation, DNA was ligated in $100 \mu \mathrm{l}$ at $16^{\circ} \mathrm{C}$ overnight using T4 DNA ligase and then used as template for 40 cycles of inverse PCR. For the right end of the transposon, we used the outer primer P-PCR [5',CGACGGGACCACCTTATGTTATTTCATCATG] that recognizes the $5^{\prime}$ and $3^{\prime}$ terminal ends and the inner primer P-ry [5',GATTGTTGATTAACCCTTAGCATGTCCGTG]. For the left end, we used P-PCR as outer primer and the P-lac oligonucleotide [5',AGCTGGCGTAATAGCGAAGAGGCCCGCA] as the inner primer. PCR was performed with $0.1-0.4$ fly equivalents and $0.1 \mu \mathrm{l}$ of KlenTaq (Wayne Barnes, Washington University Medical School, St Louis, MO) in a $50 \mu \mathrm{l}$ reaction. PCR was monitored by analyzing $20 \%$ of the sample on a $1 \%$ agarose gel, where a single strong band often could be visualized. Of this complex reaction, $10 \%$ was radiolabeled with ${ }^{32} \mathrm{P}$ by random hexamer priming and used to probe blots of restricted $\lambda$ phage and $\mathrm{P} 1$ phage containing $\sim 15$ to $\sim 100 \mathrm{~kb}$ of genomic DNA from the $60 \mathrm{AB}$ region.

Direct PCR. We used a $\mathrm{P}$ element primer (P-PCR) and primers from Drosophila PHM sequences (called -280: 5',AAACGTTGGGCATCAGGA, and called -380: 5',GTTCATCGTGGCATTAGG) in $35 \mathrm{cy}-$ cles of direct PCR to amplify flanking regions that were suspected to lie within the PHM gene. The PHM oligonucleotide names derive from their positions within PHM cDNA 1 . Reactions contained 0.4 fly equivalents of genomic DNA and $0.1 \mu \mathrm{l}$ of KlenTaq in a volume of $50 \mu \mathrm{l}$.

\section{RESULTS \\ Drosophila extracts contain both PHM and PAL enzyme activities}

In vertebrate systems, peptide $\alpha$-amidation occurs via two sequential enzymatic steps. These steps are catalyzed by a monooxygenase and a lyase that are cosynthesized as adjacent domains of the PAM gene product (Fig. 1). We screened Drosophila adult head extracts for the presence of the two enzyme activities, PHM and PAL. Both soluble and detergent-extracted proteins were fractionated by gel filtration and assayed for enzyme activity using the synthetic tripeptide substrates $\alpha-N$-acetyl-Tyr-Val-Gly or $\alpha-N$ acetyl-Tyr-Val- $\alpha$-hydroxyglycine (Perkins et al., 1990) (Fig. 2). We detected a single peak of PHM activity, with an apparent molecular mass of $35 \mathrm{kDa}$, in both extraction conditions (Fig. $2 A$ ). The amount of soluble Drosophila PHM activity was much greater than the amount of dPHM activity extracted from the insoluble pellet on addition of detergent. We also detected a single peak of PAL activity with an apparent molecular mass of $45 \mathrm{kDa}$ (Fig. $2 C)$; most of the PAL activity was recovered in the soluble fraction, with little additional PAL activity present after detergent extraction of the insoluble fraction of adult heads. Thus, both of the enzymatic activities involved in peptide amidation in vertebrate systems are detectable in Drosophila tissues. In addition, the apparent molecular masses of the Drosophila PHM and PAL activities correspond closely to those of the PHM and PAL catalytic cores previously identified in tryptic digests of rat PAM (Husten et al., 1993). Activity was not associated with a protein large enough to include PHM and PAL. Although assays of vertebrate tissue extracts, under the conditions used here, generally yield several-fold more PAL activity than PHM activity, Drosophila extracts consistently yielded less PAL activity than PHM activity.

As described below, we identified a Drosophila gene encoding a
PHM protein (dPHM). We raised two rabbit polyclonal antisera to purified recombinant $\mathrm{APHM}$ protein and used them to analyze the fractions obtained by gel filtration of adult head homogenates (Fig. $2 B$ ). We found an excellent correspondence of the fractions containing an $\sim 35 \mathrm{kDa}$ PHM-like immunoreactive protein and the fractions exhibiting PHM activity. The only immunoreactive fractions were those that also contained enzymatic activity. Together this evidence stands against the possibility that larger molecular weight forms of PHM (i.e., precursors containing both PHM and PAL enzymatic domains) are prevalent in Drosophila head.

We also found both PAM-related enzyme activity in the Drosophila shi (shibere) cell line (data not shown). Tublitz et al. (1994) previously found that these cells contain a cardioaccelerating biological activity that resembles the activity of neurally derived cardioactive peptides of various insects, including Drosophila. This suggested the presence of bioactive peptides in shi cells that also could be amidated. The shi cells are thought to derive from the paired exit glial cells that lie in each of the segmental, dorsomedial neurohemal organs of the ventral ganglion (Chiang et al., 1994).

\section{Properties of the Drosophila enzyme PHM}

Using the peak fractions from the Superose column, we compared the properties of Drosophila PHM to the properties of rat PHM (Husten and Eipper, 1991) (Fig. 3). Vertebrate PHMs all require copper and exhibit acidic pH optima (Eipper et al., 1993, 1995). The Drosophila PHM also required copper, with an optimal copper concentration from $\sim 0.5$ to $2 \mu \mathrm{M}$. The $\mathrm{pH}$ optimum for $\mathrm{dPHM}$ was $\sim 5.0$, and its optimal ascorbate concentration was $\sim 0.5 \mathrm{~mm}$. These values are very similar to those described for all of the vertebrate PHMs (Eipper et al., 1993, 1995). We performed kinetic studies to determine the affinity of dPHM for its substrate (Fig. 3D). The data obtained followed Michaelis-Menton kinetics; the $K_{\mathrm{m}}$ of dPHM for $\alpha-N$-acetyl-Tyr-Val-Gly was $2.2 \pm 0.1 \mu \mathrm{M}$. By comparison, the $K_{\mathrm{m}}$ of bovine PHM for the same substrate was $10 \pm 2 \mu \mathrm{M}$ (Eipper et al., 1991). Vertebrate PAL requires the presence of a divalent ion for activity, although the specificity of this requirement is not so great as that of vertebrate PHM for copper (Eipper et al., 1991). dPAL activity was broadly sensitive to divalent metal ions, but its profile of sensitivity differed from that of mammalian PAL (data not shown).

\section{Identification of a Drosophila PHM cDNA}

Given the presence of enzyme activities in tissue and shi cell extracts, the size, properties, and catalytic requirements of which were similar to vertebrate PHM and PAL, we undertook a search for the Drosophila gene(s) encoding these activities. Initially, we found relevant sequences using RNA from the shi cell line. We used a PCR strategy that was based on the use of three degenerate primers chosen from previous structure-function analyses of PHM and DBM (Stewart and Klinman, 1988; Eipper et al., 1995) (see Fig. 1). In this way, we isolated a single fragment of the expected size: sequence analysis indicated the presence of key features characteristic of PHM, and the fragment subsequently was used to identify a longer insert (cDNA 1) from a shi cell cDNA library. This putative $d P H M$ cDNA clone was 1424 bp in length [including a poly(A) tail of 27 nucleotides] and encodes a protein with an open reading frame of 365 amino acids (Fig. 4).

The deduced protein begins with a hydrophobic $\mathrm{NH}_{2}$ terminus that has the properties of a signal sequence and displays a great deal of similarity to vertebrate PHMs (Fig. 5). Over the catalytic core of the enzyme, there is $40 \%$ sequence identity between rat and Drosophila PHM and complete identity extending up to nine consecutive 


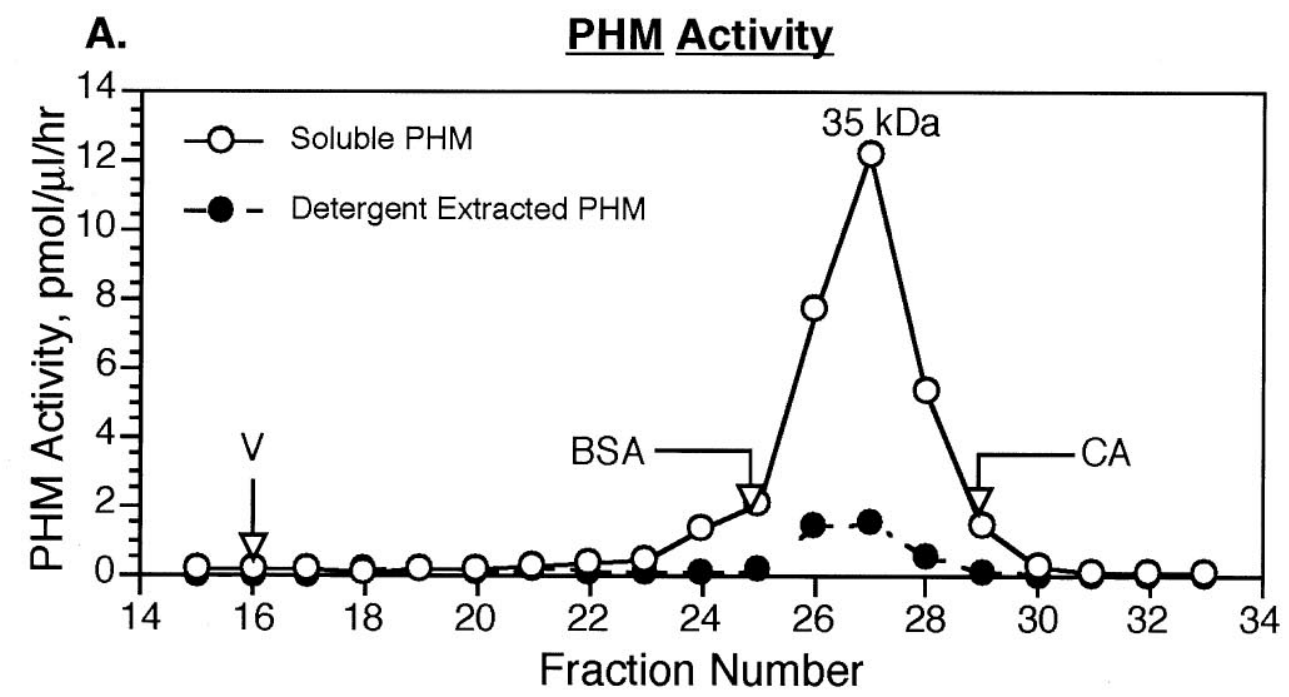

B.

dPHM Western

$\begin{array}{lllllllll}\text { Fraction \# } & 17 & 18 & 19 & 25 & 26 & 27 & 28 & 29\end{array}$

Soluble dPHM

$--38 \mathrm{kDa}$

Detergent Extracted $\mathrm{dPHM}$

PAL Activity

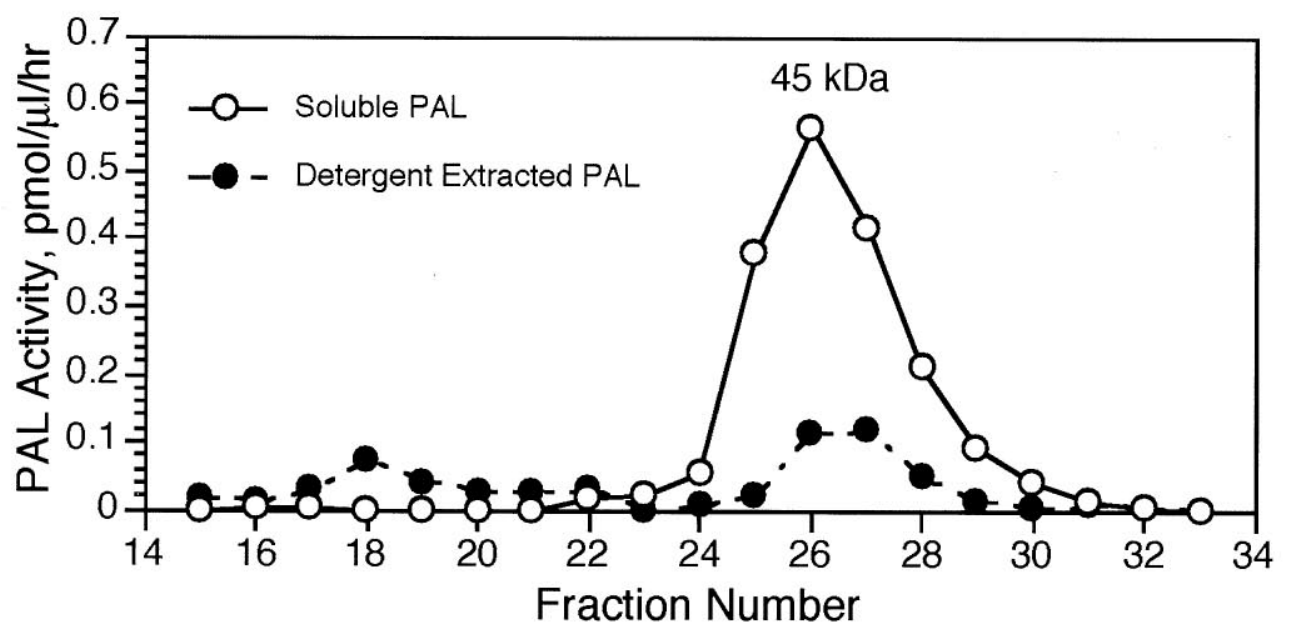

Figure 2. Size exclusion chromatography. A, PHM activity in various fractions from a Superose 12 FPLC purification in the presence or absence of detergent. $B$, Western blot analyses of the fractions from the two analyses in $A$, using the anti-dPHM antiserum. To correct for the lower activity in the detergent extracts, we analyzed a larger volume of sample. $C$, PAL activity in the same fractions as in $A$. The size markers that bracket the enzyme activities are shown: $B S A$, bovine serum albumin, $69 \mathrm{kDa}$; $C A$, carbonic anhydrase, $30 \mathrm{kDa}$. A protein the size of mammalian integral membrane PAM-1 is expected to elute in fractions $17-19$.

residues. Other notable features of similarity include (1) eight cysteine residues found in homologous positions in all PHMs and DBMs, and (2) two histidine-rich sequence clusters (HHM, aa 95-97, and HTH, aa 241-243) that are thought to be important for the binding of copper to the mono-oxygenase (Eipper et al., 1995). The presence of several other highly conserved regions suggests that these regions play a previously unrecognized role in catalysis. A stop codon occurs immediately past what is recognized as the catalytic core of rat 


\section{A. Copper Dependence}

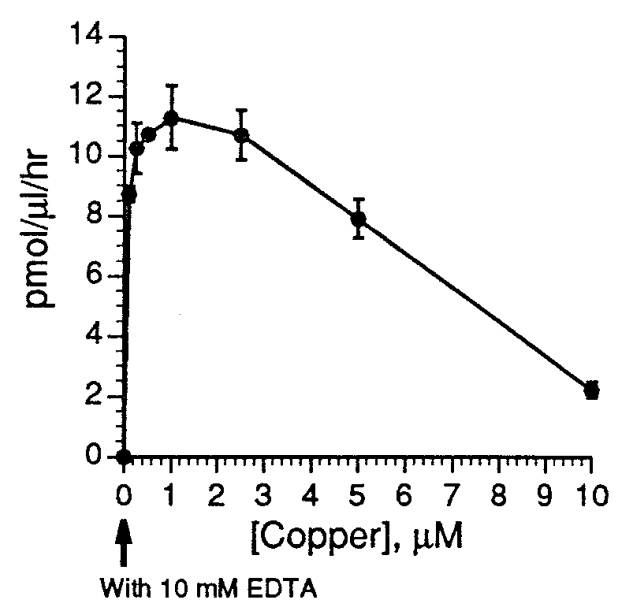

\section{Ascorbate Dependence}

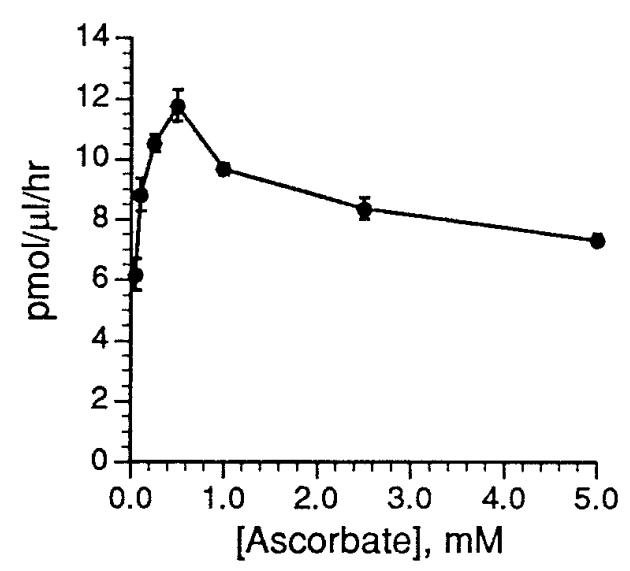

B. pH Dependence

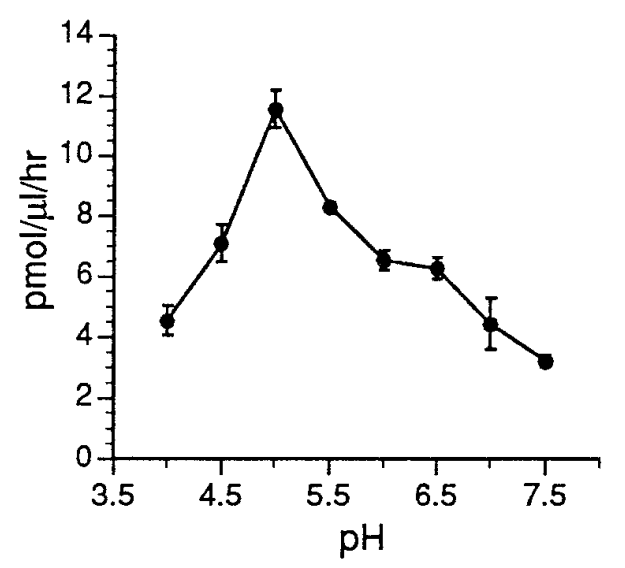

D. Eadie-Hofstee Plot

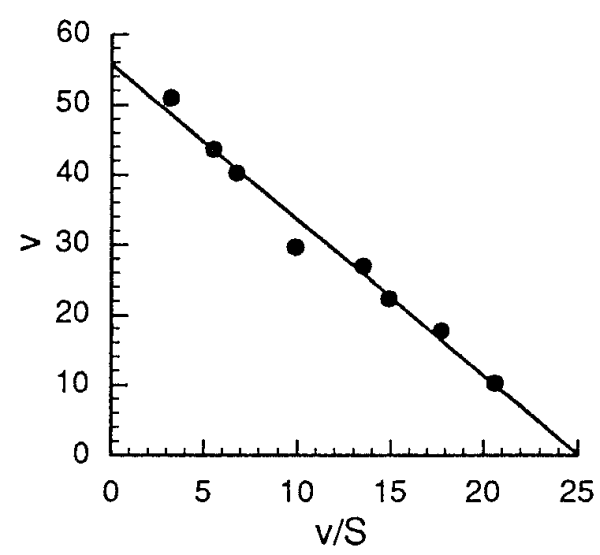

Figure 3. The peak fractions from a superose 12 column containing partially purified dPHM were assayed. $A$, Copper concentration was varied in the presence of $0.5 \mathrm{~mm}$ ascorbate, $0.1 \mathrm{mg} / \mathrm{ml}$ catalase, and $100 \mathrm{~mm}$ Na MES, pH 5.0, at a substrate concentration of $0.5 \mu \mathrm{M}$ Ac-YVG. $B, \mathrm{pH}$ was varied using $100 \mathrm{mM}$ Na MES buffer of the indicated $\mathrm{pH}$ in the presence of $1.0 \mu \mathrm{M} \mathrm{CuSO}_{4}, 0.5 \mathrm{~mm}$ ascorbate, and $0.1 \mathrm{mg} / \mathrm{ml}$ catalase at a substrate concentration of $0.5 \mu \mathrm{M}$ Ac-YVG. $C$, Ascorbate concentration was varied in the presence of $1.0 \mu \mathrm{M} \mathrm{CuSO}{ }_{4}, 0.1$ $\mathrm{mg} / \mathrm{ml}$ catalase, and $100 \mathrm{~mm} \mathrm{Na}$ MES, $\mathrm{pH}$ 5.0, at a substrate concentration of $0.5 \mu \mathrm{M}$ Ac-YVG. $D$, Eadie-Hofstee plot for dPHM using Ac-YVG as the substrate $(0.5-16 \mu \mathrm{M})$ in the presence of 1.0 $\mu \mathrm{M} \mathrm{CuSO}_{4}, 0.5 \mathrm{~mm}$ ascorbate, $0.1 \mathrm{mg} / \mathrm{ml}$ catalase, and $100 \mathrm{~mm}$ Na MES, pH 5.0. Numbers are means from assays performed in quadruplicate. The entire experiment was performed two times with similar results.
PHM and is followed by a 201 nucleotide $3^{\prime}$-untranslated region and a poly $(\mathrm{A})^{+}$tail of 27 nucleotides. Although clearly encoding a PHM protein, the Drosophila cDNA encodes a monofunctional enzyme. No cDNAs encoding bifunctional PAM proteins were identified in the $s h i$ cell cDNA library.

\section{Activity of Drosophila PHM in heterologous cells}

We tested the functional properties of the dPHM protein after its expression in either of two heterologous cell lines. We transiently transfected $d P H M$ cDNA 1 into hEK-293 cells and into CHO cells; we assayed cell extracts and medium and found PHM activity in both (Fig. 6). No PAL activity was detected. A cDNA encoding rat PHM was expressed for comparison. Similar amounts of PHM activity were observed after expression of vector encoding rPHM or dPHM. Adjusted for the volumes of extracts and medium, the rate of secretion of enzyme activity over the $9 \mathrm{hr}$ secretion period was $12 \%$ of cell content per hour for both Drosophila and rat PHM. Thus the $A P H M$ gene encoded an active, monofunctional secreted PHM enzyme.

\section{Expression of the $d P H M$ gene in Drosophila heads}

We used shi cell cDNA 1 as a probe to isolate three distinct cDNAs from an adult Drosophila head cDNA library; the sizes of each were very similar to that of cDNA 1 . Sequence analysis revealed the cDNAs differed only in the extent of $5^{\prime}$ or $3^{\prime}$ untranslated sequence; each encoded the same 365 amino acid monofunctional PHM protein. The shi cell cDNA 1 contains the longest $5^{\prime}$ untranslated region and is the only cDNA in the set that includes a poly(A) tail at its $3^{\prime}$ end. cDNA 14 (from adult head) contains an additional 93 bp of $3^{\prime}$ untranslated sequence, i.e., past the point of polyadenylation in cDNA 1 ; this additional $3^{\prime}$ sequence is found contiguously within genomic sequence and so likely indicates alternative sites of polyadenylation and not alternative RNA splicing among $d P H M$ transcripts (see below).

RNA blot analyses of both the shi cell line and adult head indicated the presence of a single PHM transcript size class of $\sim 1.7 \mathrm{~kb}$ (Fig. $7 A$ ). The Northern blot results are consistent with the hypothesis that the cDNAs so far defined are representative of the prevalent PHM RNAs. Vertebrate mRNAs encoding bifunctional PAM proteins are 4-4.5 kb (Eipper et al., 1992); the Drosophila transcripts identified with an authentic $P H M$ probe are not long enough to encode both PHM and PAL. We did not find any evidence of higher molecular weight transcripts in Drosophila.

\section{The structure of the $d P H M$ gene}

Southern blot analysis, using the shi cell $d P H M$ cDNA 1 as probe, indicated $d P H M$ sequences are present in single copy in the 


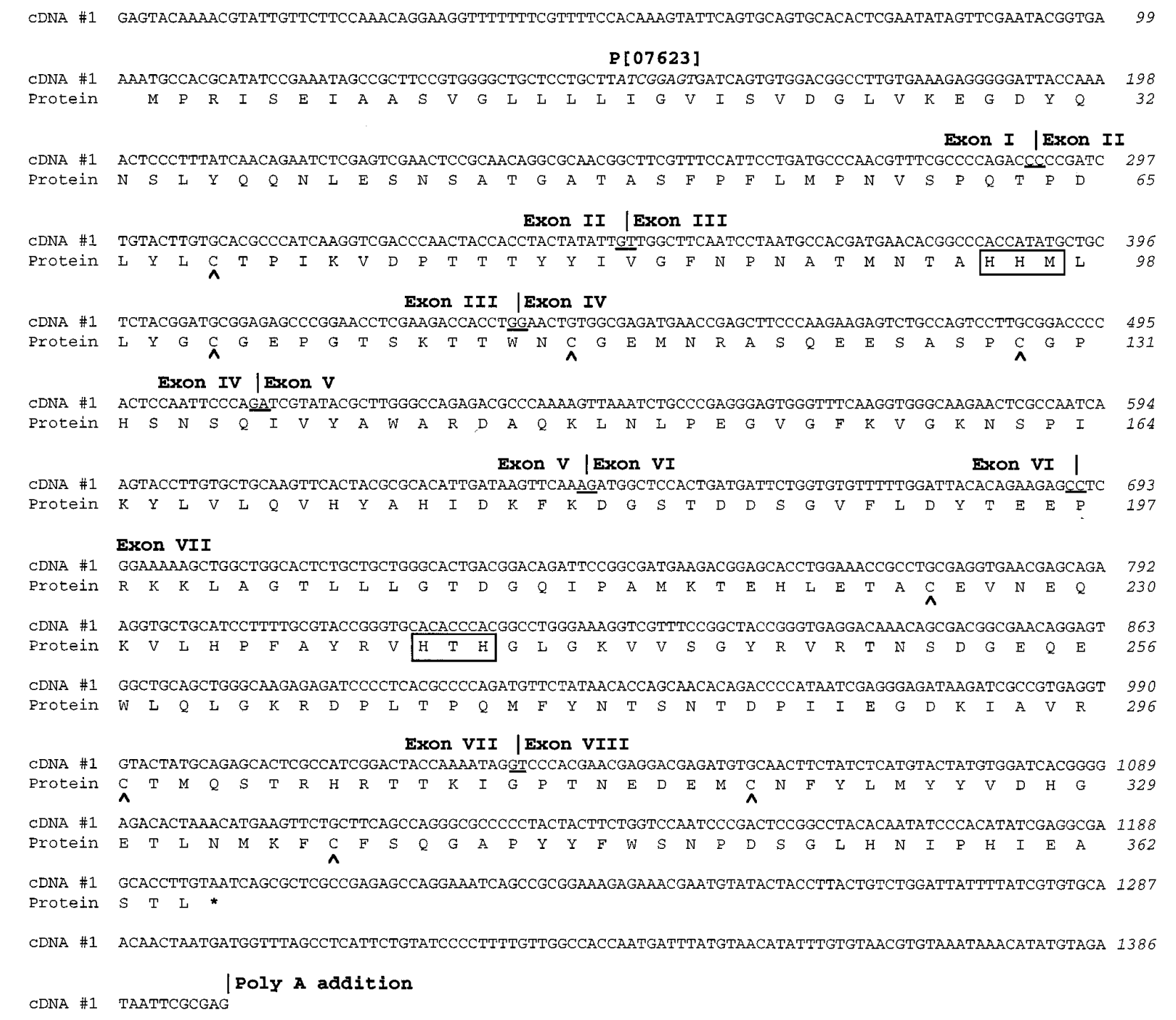

Figure 4. Sequence of $P H M$ cDNA 1 recovered from a shibere cDNA library. The deduced protein sequence of the longest open reading frame is listed below the DNA sequence. Exon boundaries are indicated and are based on comparison to genomic sequence; underlined dinucleotides represent the last and first base, respectively, of adjacent exons. P[07623] indicates the position of a P element insertion (described in later figures); the 8 bp in italics at this position are duplicated in the insertion stock. Conserved cysteine residues are marked by arrowheads; two conserved Histidine-rich clusters are marked by boxes.

haploid Drosophila genome (Fig. $7 B$ ). With the same probe, we found genomic sequences that corresponded to all available $d P H M$ cDNAs within a single genomic phage, called M7. We used blotting and sequence analysis to identify exon boundaries (see Fig. 4) and to define the organization of this gene (Fig. 8). Although we lack precise definition of the $d P H M$ start site, the gene contains at least eight exons.

Comparison of the exon/intron structure of $D P H M$ to that of the PHM domain of the rat $P A M$ gene (Fig. $8 B$ ) indicates a highly similar organization. Six of the seven introns in $d P H M$ occur within identical amino acids to those containing introns in mammalian $P A M$. A further similarity is found on examination of the intron junctions: exons are interrupted by introns that occur between codons (type 0 ) or within them (type 1 , after one nucleotide; type 2, after two nucleotides). In the case of $P H M$, the rat and Drosophila genes have comparable "types" at all six conserved intron junctions. Unlike the rat $P H M$ sequences, which map over more than $76 \mathrm{~kb}$ (Ouafik et al., 1992), sequences encoding the $d P H M$ open reading frame extend over only $\sim 3 \mathrm{~kb}$ of genomic DNA. We have found no evidence for the occurrence of alternative splicing in the $d P H M$ gene. Also, standard low stringency screening methods failed to detect the presence of PAL-encoding sequences near (i.e., within $\sim 10 \mathrm{~kb}$ ) the identified PHM gene. Thus, the $A P H M$ gene seems highly homologous to the mammalian $P A M$ gene, except in lacking a PAL-encoding domain.

\section{Genetic evidence for separate PHM and PAL genes}

We identified a $\mathrm{P}$ element insertion line within the PHM gene and measured PHM and PAL enzyme levels in that mutant background. We first assigned the PHM gene position to the interval 60A12-16, at the end of chromosome arm $2 \mathrm{R}$ by hybridization to polytene chromosomes. To confirm this assignment, we analyzed available chromosomal deficiencies of the 59-60 interval by Southern blot analysis: we found that $A P H M$ is deleted in each of two overlapping deficiencies, $\mathrm{Df}(2 \mathrm{R}) \mathrm{G} 10-7-5$ and $\mathrm{Df}(2 \mathrm{R})$ orBr-6, but not in several other deficiencies in the region (data not 


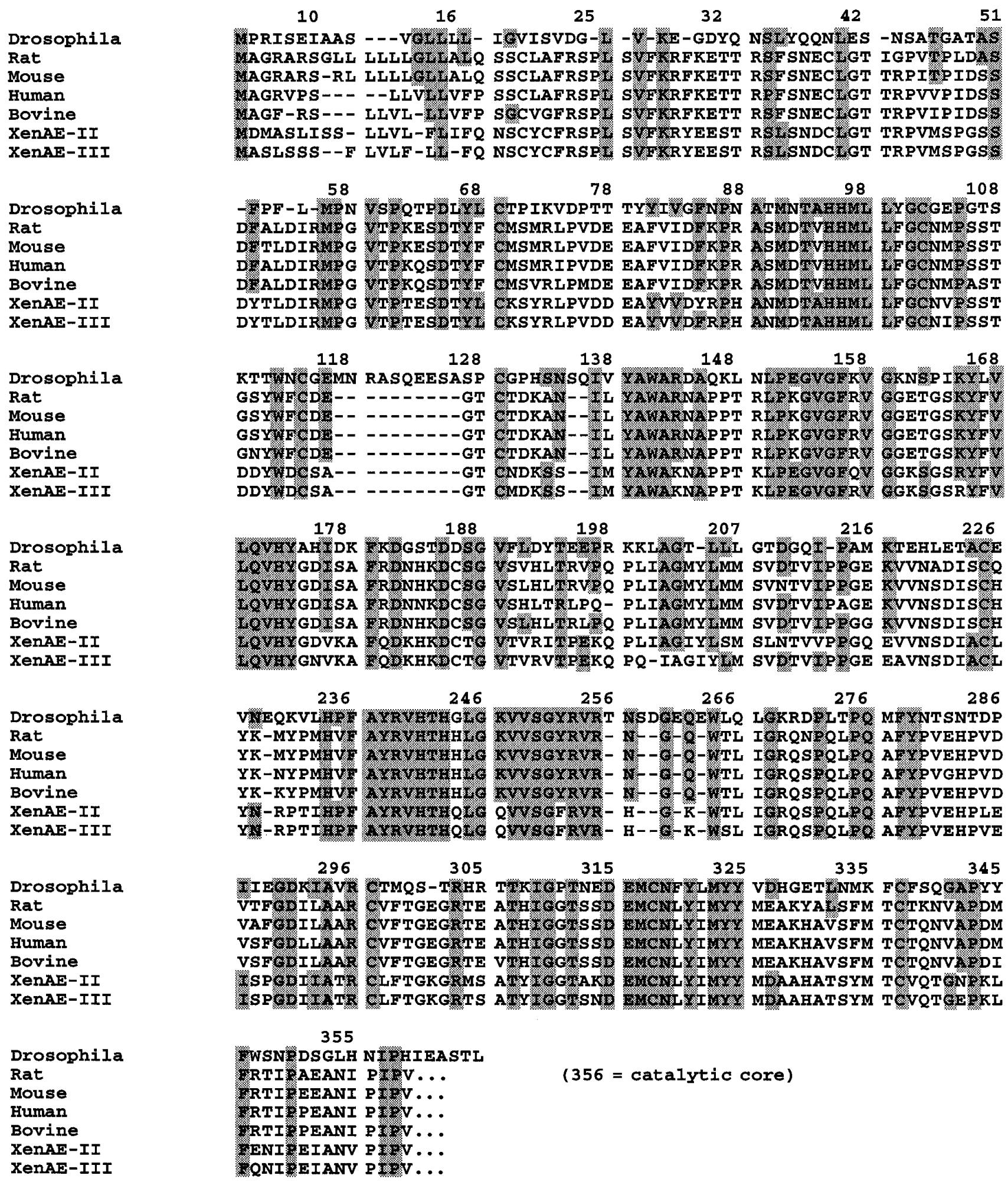

Figure 5. Comparison of PHM protein sequences. The predicted protein sequence of dPHM is compared with that of PHMs from various vertebrate species. Shaded residues indicate identity between the insect and any of the vertebrate species listed. PHM sequences from GenBank; references in Eipper et al. (1992, 1993).

shown). We analyzed $13 \mathrm{P}$ element stocks of the 60A/B interval by inverse PCR for the closest possible insertion. Among these, the flanking sequence of a single line, $P$ [07623], hybridized uniquely to the $d P H M$ genomic phage M7: this suggested an insertion within $8 \mathrm{~kb}$ of the $P H M$ gene.
We next used direct PCR, restriction, and sequence analysis of PCR products to place the $\mathrm{P}[07623]$ insertion within the $d P H M$ open reading frame (Fig. 9). The host sequence at the insertion (Fig. $9 A$ ) includes an 8 bp target site duplication that is characteristic of $\mathrm{P}$ element integrations (O'Hare and Rubin, 1983); the 
TRANSIENT EXPRESSION OF PHM VECTORS IN hEK-293 CELLS

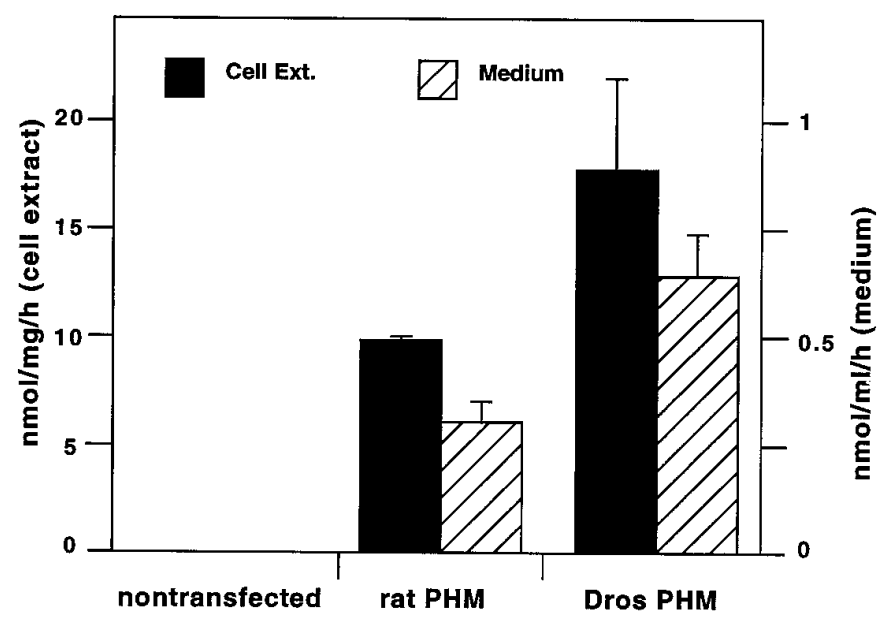

Figure 6. Functional expression of the cloned Drosophila PHM cDNA. The cDNA 1 was subcloned into the pCIS.2CXXNH mammalian expression vector, and transient expression was performed with hEK-293 and $\mathrm{CHO}$ cells. Both cell lines produced activity in each of two experiments. The results from one experiment with hEK-293 cells are presented here, as the average of duplicates in the single assay. Error bars show range.

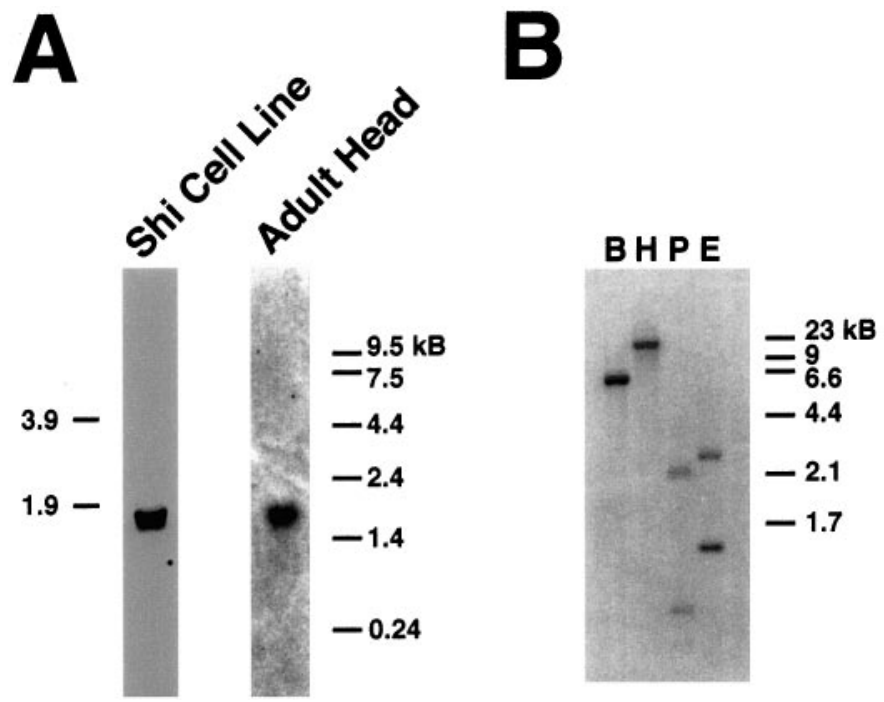

Figure 7. $A$, Northern blot analysis of $d P H M$ RNAs. Left, Total RNA (5 $\mu \mathrm{g})$ derived from the shi cell line and probed with PHM cDNA 1. Right, Poly $(\mathrm{A})^{+}$RNA $(10 \mu \mathrm{g})$ derived from adult head and probed with $P H M$ cDNA 11. Both experiments reveal signals derived from a 1.6-1.8 kb class of RNAs. B, Southern blot analysis of Drosophila genomic DNA. In this experiment, 10 fly equivalents were restricted with each of the enzymes listed and loaded into individual lanes. The blot was probed with $d P H M$ cDNA 11 . The signals generated are consistent with the presence of a single $d P H M$ locus. B, Bam HI; H, HindIII; P, PstI; E, EcoRI.

precise insertion site is located near the end of the predicted signal sequence of the pre-PHM protein (Fig. 9B). To confirm the location of this element within the $\mathrm{P}[07623]$ stock independently, we used Southern blot analysis of total genomic DNA and found specific polymorphisms that were consistent with that prediction (Fig. 10).

We asked whether PHM protein expression was affected by this insertional mutation. Because the insertion displays homozygous lethality (see below), we tested PHM protein levels in heterozygous adult heads. We assayed PHM and PAL levels in three stocks: in $\mathrm{P}$ [07623], in a distinct insertion stock also of the $60 \mathrm{~A}$ region, $\mathrm{P}$ [03101], and in a control stock that also contained a second chromosome balancer. PHM enzyme levels were reproducibly lower in heterozygous P[07623] animals by about twofold (Fig. 11). Interestingly, PAL levels were elevated in this insertion line so that the PHM/PAL ratio was lowered further. Thus, the $\mathrm{P}[07623]$ insertion severely reduces the expression of PHM levels in heterozygous animals, without concomitant reduction of PAL levels, as predicted by a two-gene hypothesis.

\section{A lethal phenotype associated with the $d P H M P$ element insertion}

The P[07623] stock is homozygous lethal, and the lethality segregates with the second chromosome. Further, complementation analyses with the available panel of $60 \mathrm{AB}$ mutant stocks (deficiencies and $\mathrm{P}$ element insertions) indicated that all other $\mathrm{P}$ insert lines complemented $\mathrm{P}$ [07623], as did all but three deficiency stocks (Table 1). These complementation data are consistent with the assignment of PHM to the 60A12-16 interval that was based on molecular information, and they localize the lethality associated with the $\mathrm{P}[07623]$ insertion line to the region of overlap between the two deficiency stocks (i.e., to the 59F-60A12-16 region).

To implicate the insertion further as the cause of the lethality, we used a genetic source of transposase to mobilize the P element in stock [07623]. We recovered numerous independent revertants of the white ${ }^{+}$phenotype. The white ${ }^{+}$eye phenotype is the marker indicating the presence of the transposon: the lethality associated with the $\mathrm{P}[07623]$ stock was lost in 11 of 38 independent revertants of the white marker. Molecular analysis of some of the viable revertant lines by Southern blot analysis (Fig. 10) indicated a complete removal of the insertion without large-scale disruption of host sequences. This is evidence that the homozygous lethality of the original $\mathrm{P}[07623$ ] chromosome is attributable to the presence of the insertion. Taken together with measurements of lowered PHM enzyme levels (Fig. 11), the evidence indicates that a lethal phenotype is obtained from mutation of the $P H M$ gene.

\section{dPHM protein expression}

Staining of larval CNS with the affinity-purified antisera indicated widespread expression of dPHM-like protein throughout all levels of the CNS, as well as in other tissues, including endocrine glands and gut (Fig. 12). Antibody specificity was deduced by comparison with tissues that were stained with preimmune serum. This expression was limited to a small number of CNS neurons (approximately a few hundred) that displayed very high levels of PHMlike immunoreactivity (Fig. 12a). Among stained neurons, immunoreactivity was seen both in cell bodies and within neuropil regions. The latter represents stained neuronal processes and also may include glial staining. PHM antibody staining was also prevalent in secretory cells of the Ring Gland (Fig. 12B), salivary gland (not shown), and in diverse cells at all levels of the midgut (Fig. 12C). In the CNS, several strongly stained cells were identifiable as neuroendocrine neurons (Nassel et al., 1994; Nassel, 1996) because they projected immunoreactive axons to defined neurohemal organs like the Ring Gland (Fig. 12b) or the dorsal neurohemal organs of the ventral ganglion. Many PHM-positive neurons had positions similar to those of previously identified peptidergic cells. We verified such identity in the case of several dFMRFamide-expressing neurons using a Drosophila stock containing a dFMRFamide- $\beta$-galactosidase construct called pWF3 (Schneider et al., 1993). As shown in Figure 13, the lacZ-positive 


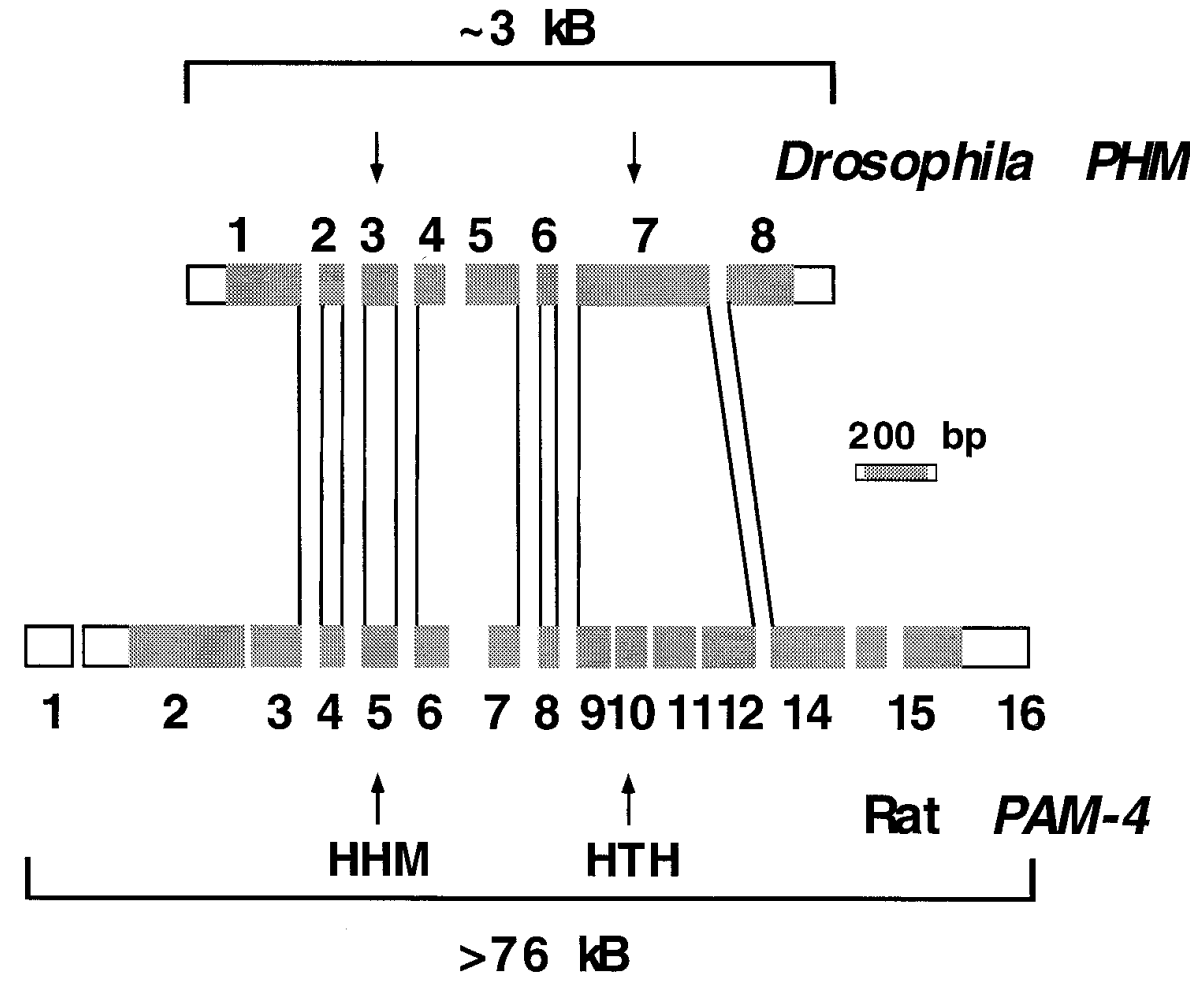

Figure 8. Gene organization indicates Drosophila $\mathrm{PHM}$ and rat $P A M$ are closely related genes. Rat $P A M-4$ was chosen for comparison because its use of an alternate poly(A) ${ }^{+}$addition site means it encodes a monofunctional PHM protein (Eipper et al., 1993). The shaded areas within the exons indicate the approximate boundaries of the protein-coding sequences. Because the $5^{\prime}$ end of the Drosophila gene has not been mapped precisely, the exon marked number 1 may not be the very first. Brackets above and below the genes indicate the difference in total locus size. In this schematic, the relative size proportions of exons have been preserved, whereas those of introns are not to scale.

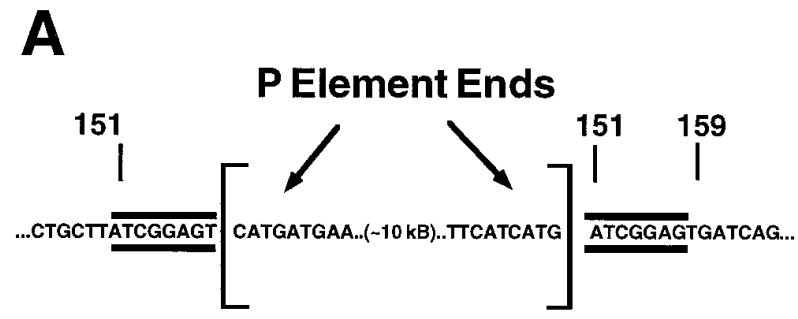

B

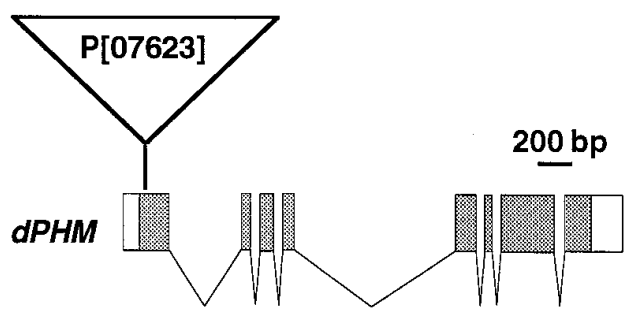

Figure 9. The P[07623] insertion maps within the $P H M$ gene. $A$, Partial representation of DNA sequence analysis indicates the precise position of the $\mathrm{P}$ insertion and the presence of an $8 \mathrm{bp}$ repeat of host sequence (bp 151-159, marked by double horizontal bars) flanking its ends. $B$, The position of the $\mathrm{P}$ insertion within the transcription unit is indicated in the map of $d P H M$ exons.

SE2 interneurons of the subesophageal neuromeres ( $A$ and $B$ ) and the neuroendocrine Tv and Tva neurons of thoracic neuromeres $(C$ and $D)$ were among the strong PHM-staining neurons. Thus, in the case of certain identified neurons, high levels of PHM expression correlate with a peptidergic neuronal phenotype.

\section{DISCUSSION}

The study of peptide amidation is fundamental to the understanding of neuropeptide biosynthesis (Eipper et al., 1992).
The current work extends our understanding of peptide amidation by initiating its analysis in a model genetic system, Drosophila, where its roles and regulation in vivo may be addressed directly. Previous studies have suggested that neuropeptide processing in Drosophila is closely related to that of vertebrates by virtue of finding genes encoding related processing enzymes (Roebroek et al., 1991; Hayflick et al., 1992; De Bie et al., 1995; Settle et al., 1995). Extracts of Drosophila head contain both the mono-oxygenase and lyase activities associated with peptide $\alpha$-amidation in vertebrates (Fig. 2). Like all vertebrate PHMs, the Drosophila PHM enzyme was copperand ascorbate-dependent and exhibited a micromolar $K_{\mathrm{m}}$ for its peptidylglycine substrate. In contrast to all species examined previously, however, Drosophila PHM is not part of a bifunctional $P A M$ gene. Our results predict the presence of separate $P H M$ and $P A L$ genes in Drosophila and argue for a fundamental difference between species in the organization and regulation of genes encoding these important neuropeptide biosynthetic enzymes. Previous biochemical work on insects is consistent with our present molecular data: Zabriskie et al. (1994) purified a monofunctional PHM enzyme that lacked PAL activity from honeybees. The separation of $P H M$ and $P A L$ into distinct genes, as in Drosophila, therefore may be broadly representative of many insect and perhaps invertebrate species in general.

\section{$d P H M$ is homologous to the PHM portion of mammalian PAM}

The gene encoding rat PAM is large $(>180 \mathrm{~kb})$, contains at least 28 exons, and produces several alternatively spliced transcripts (Eipper et al., 1992; Ouafik et al., 1992; Hand et al., 1996). In the rat, the major $P A M$ transcripts encode bifunctional integral membrane proteins. Transcripts encoding monofunctional, soluble PHM (e.g., PAM-4, Fig. 1) are generated only as quantitatively minor forms and only when a poly $(\mathrm{A})$ addition site downstream of 

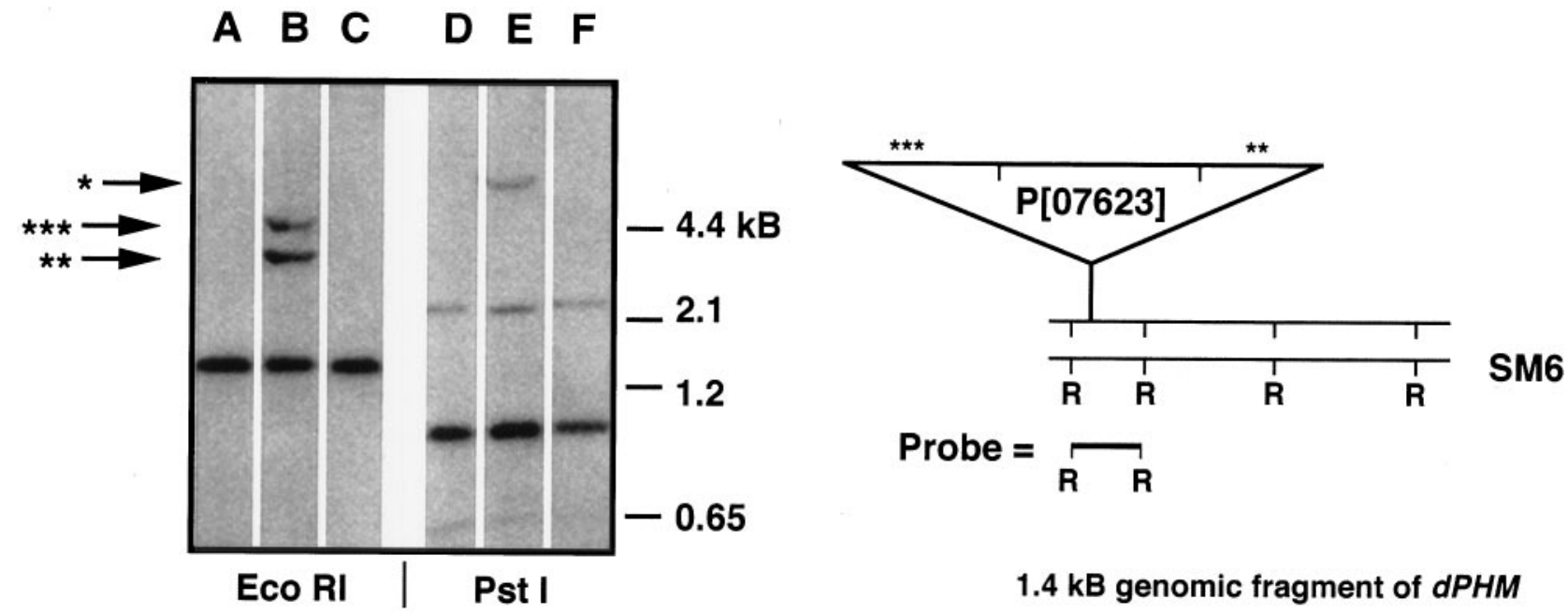

\section{$1.4 \mathrm{kB}$ genomic fragment of $d P H M$}

Figure 10. Genomic Southern blot analysis of several Drosophila stocks with a PHM gene probe. An $\sim 1.4$ kb R1 fragment was used to probe PstI- and EcoRI-digested genomic DNAs from each of three separate stocks. Lanes $A$ and $D$ (w-; Sco/SM6) represent the background stock. Lanes $B$ and $E$ (w-; $\mathrm{P}[07623] / \mathrm{SM} 6$ ) represent the $\mathrm{P}[07623]$ insertion heterozygous to the SM6 balancer chromosome. Lanes $C$ and $F$ (w-; R2-P[07623]/SM6) represent a viable revertant stock of P[07623]. The schematic to the right presents an interpretation of the hybridization pattern according to the restriction map of EcoRI sites. The asterisks and arrows mark the polymorphic bands consistent with the presence of the $\mathrm{P}$ element in the $d P H M$ gene. The positions of the bands from the EcoRI digest are included in the schematic; the single asterisk indicates the presence of a polymorphism predicted in PstI-digested DNA in the $\sim 9 \mathrm{~kb}$ range. Note the restoration of the background pattern of hybridization in the revertant stock.

Figure 11. Enzyme activity measurements in $\mathrm{P}$ element insertion stocks [07623] and [03101] compared with a balancer control stock. PHM and PAL activity levels in adult head homogenates were measured in several independent experiments; here five measurements of PHM and four measurements of PAL were used to compose these histograms. $t$ tests were calculated using Excel. $\mathrm{CyO}$ refers to the Curly Oster second chromosome balancer; Sco refers to a marked second chromosome bearing a mutation of the Scutoid locus; SM6 is a second chromosome balancer.

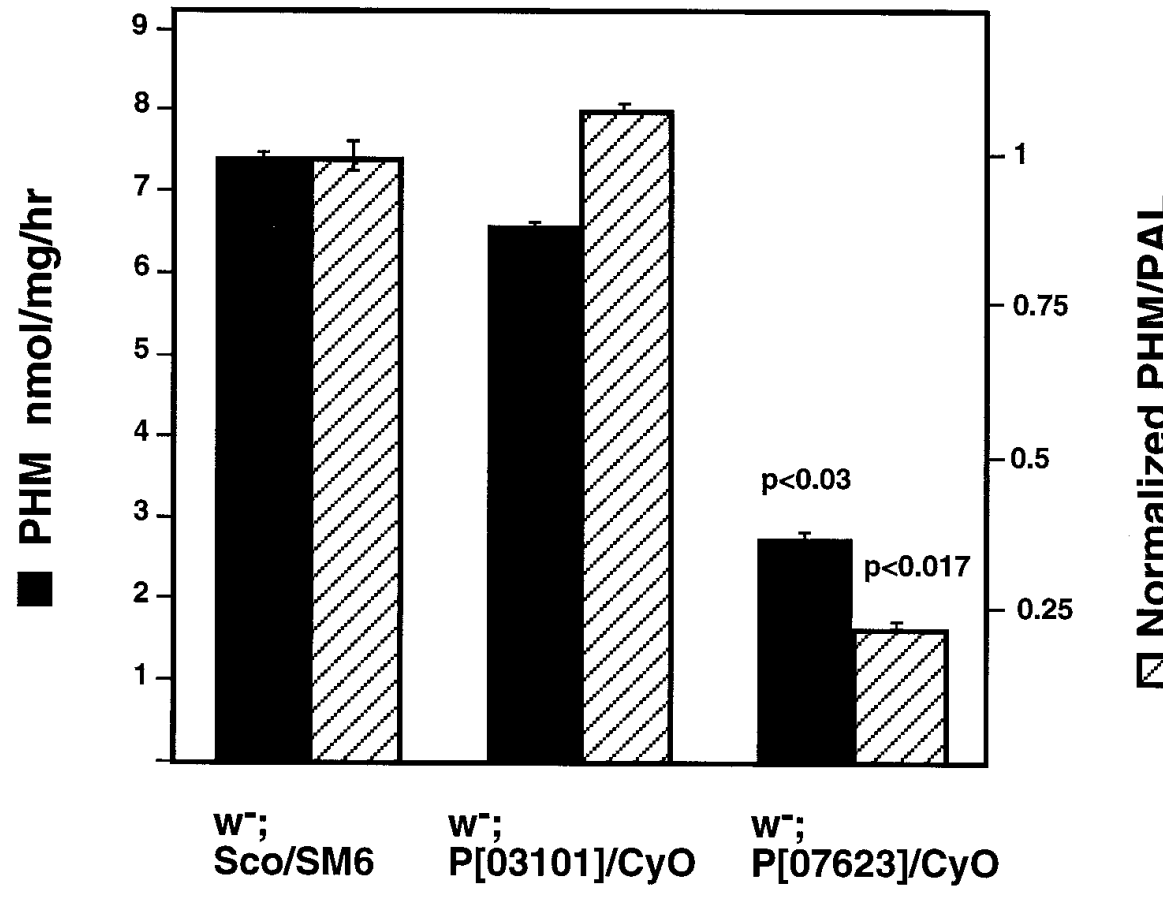

the activity of monofunctional PHM is higher when separated from the PAL domain (Husten et al., 1993).

$d P H M$ is homologous to the $P H M$ portion of mammalian $P A M$ and encodes a protein with authentic PHM activity (Fig. 6). Drosophila and rat PHM exhibit $\sim 41 \%$ amino acid sequence identity over their catalytic cores (52\% similarity) (Fig. 5). This degree of identity is significantly greater than the $29 \%$ sequence identity observed for rat $P H M$ and rat dopamine $\beta$-mono-oxygenase over the same region (Wang et al., 1990). Also, a bona fide Drosophila DBM homologue (tyramine $\beta$ hydroxylase, which catalyzes the conversion of tyramine yield soluble, monofunctional PHM and PAL. Both PHM and PAL are active as part of the bifunctional PAM protein, although 


\begin{tabular}{lll}
\hline \multicolumn{1}{l}{ Table 1. Complementation analysis of the P[07623] stock } \\
Stock tested & $\begin{array}{l}\text { Cytological } \\
\text { location }\end{array}$ & $\begin{array}{l}\text { Number of trans-heterozygotes: } \\
\text { total number }\end{array}$ \\
\hline P elements & & \\
P[1753] & 60A & 39: 113 \\
P[06003] & 60A5-9 & 24: 95 \\
P[09201] & 60A8-11 & 27: 115 \\
P[942] & 60A8-11 & 12: 52 \\
P[01015] & 60A10-14 & 36: 105 \\
P[1390] & 60B1-2 & 32: 100 \\
P[04209] & 60B2-3 & 29: 116 \\
P[04405] & 60B2-4 & 28: 88 \\
P[04201] & 60B3-4 & $44: 124$ \\
P[03101] & 60B5-6 & 26: 76 \\
P[K13409] & 60B6-7 & $34: 126$ \\
Aberrations & & \\
Df(2R)egl2 & 59E to 60A1 & 36: 98 \\
Df(2R)bw-S46 & 59D8 to 60A7 & 27: 82 \\
Df(2R)or-BR11 & 59F6 to 60A8-16 & $0: 77$ \\
Df(2R)G10-7-5 & 59F3 to 60A8-16 & $0: 57$ \\
Df(2R)or-BR6 & 59D5 to 60B3-8 & $0: 109$ \\
Df(2R)750 & 60B8 to 60D1-2 & $60: 144$ \\
LS(2)lt[G16] & 60B8 to 60B10 & 28: 82 \\
T(Y;2)A160 & 60B to C & 21: 56 \\
\hline
\end{tabular}

to octopamine) has been identified (Monastirioti et al., 1996), and shows only $23 \%$ identity to dPHM. Finally, the exon/intron boundaries of Drosophila and rat PHM are remarkably similar (Fig. 8), suggesting that they have diverged from a common ancestral gene. From these combined data, we conclude that the $A P H M$ and $r P A M$ genes are homologous.

\section{In Drosophila separate genes encode PHM and PAL}

Although PAL enzyme activity is detectable in Drosophila tissue extracts (Fig. 2), the protein that exhibits this activity is not associated with dPHM, and we found no evidence for a bifunctional PAM gene or PAM protein in Drosophila. The sizes of the $P H M$ RNAs and cDNAs that we detected indicate that $d P H M$ is not large enough to include PAL sequences also. No PHM enzymatic activity (Fig. $2 B$ ) or immunoreactivity (Fig. $2 C$ ) was associated with a protein large enough to include both PHM and PAL enzymes. A final point of evidence concerning the putative relationship between $P H M$ and $P A L$ gene sequences comes from enzyme measurements in the $P H M$ P element insertion stock: PHM levels were decreased specifically, whereas PAL activity was somewhat elevated. Therefore, we consider it likely that a separate $d P A L$ gene will be identified.

The individual catalytic units that form several other multifunctional enzymes have been identified as separate gene products in divergent species. For example, the seven enzyme activities that constitute the single-chain mammalian fatty acid synthase occur as two nonidentical multifunctional enzymes in fungi and as seven individual genes in bacteria (Amy et al., 1992). The $P A M$ gene may have undergone similar evolutionary modifications. The eighth $d P H M$ exon (Figs. 4,8 ) encodes the final 55 of 365 amino acids, including two of the eight conserved cysteine residues as well as other residues known to be critical for mammalian PHM activity. The eighth exon of $d P H M$ corresponds to exon 14 of rat PAM, the final exon of the PHM catalytic core. Exon 15 of the rat $P A M$ gene is poorly conserved among species and forms the type of flexible, protease-sensitive linker domain observed in other multifunctional enzymes composed of independent catalytic units (Eipper et al., 1993). Exon 16 contains sequences encoding a paired basic cleavage site that allows post-translational separation of PHM from PAL. The monofunctional $d P H M$ gene does not contain exons equivalent to either rat exon 15 or 16 and thus does not correspond to the monofunctional $P H M$ transcript generated by alternative splicing of the bifunctional rat $P A M$ gene.

\section{There is differential PHM protein expression in the CNS}

In the rat CNS, Rhodes et al. (1990) found widespread expression of PAM-like immunoreactivity, with the highest levels in periventricular and supraoptic nuclei of the hypothalamus, in neocortex, and in sensory ganglia. They also found detectable levels in several non-neuronal cell types, like Schwann cells, ependyma, and oligodendroglia. These observations are in agreement with studies of transcript localization in rat: $P A M$ RNAs were especially high in specific hypothalamic nuclei but were found in nearly all major brain regions with the exception of the cerebellum (Schafer et al., 1992). We began a cellular analysis of PHM protein expression in Drosophila by studying the immunoreactive species detectable in mature larval tissues. The strongly PHMexpressing neurons were a minor subpopulation of the CNS. Based on morphological criteria, we concluded that several of these strongly staining cells were neuroendocrine. By their positions and patterns many appear identical with previously identified peptidergic neurons (Nassel, 1996); we began the process of relating identified peptidergic neurons to the pattern of PHM neuronal expression by using a marker of dFMRFamide gene expression (Fig. 13). These data support the hypothesis that, at least for some neurons, the strong expression of PHM protein is correlated with high levels of neuropeptide expression. The high degree of cellular resolution possible in the simple nervous system of Drosophila will permit a detailed examination of PHM protein expression in identified neuronal cell types. A general and more detailed description of the pattern of PHM immunolabeling at various developmental stages will be presented in a future report. The present results suggest differential and limited expression of the dPHM protein among different neuronal classes in the mature larval CNS. This pattern is broadly analogous to that found previously in the rat CNS.

\section{A transposon inserted in the PHM gene allows a genetic analysis of neuropeptide biosynthesis}

To define the functions of the dPHM protein in vivo and to analyze the contributions of amidation to the development and physiology of the animal, we wish to identify and study animals containing $d P H M$ mutations. Several mutations affecting genes critical for aminergic and cholinergic transmitter systems have been recovered in Drosophila (for review, see Restifo and White, 1990). Feany and Quinn (1995) have described a $P$ element that lies within a gene, the sequence of which is similar to that of the mammalian PACAP/GHRH family of neuropeptides and that fails to complement the behavioral phenotype of the memory mutation, amnesiac. Until this work, there was no information regarding the genetics of Drosophila neuropeptide biosynthesis.

The $\mathrm{P}[07623]$ insertion reveals a lethal phenotype that likely is attributable to disruption of the $d P H M$ gene. This insertion represents a mutant allele of $P H M$, because PHM enzyme levels are diminished specifically (Fig. 11). Significantly, inde- 

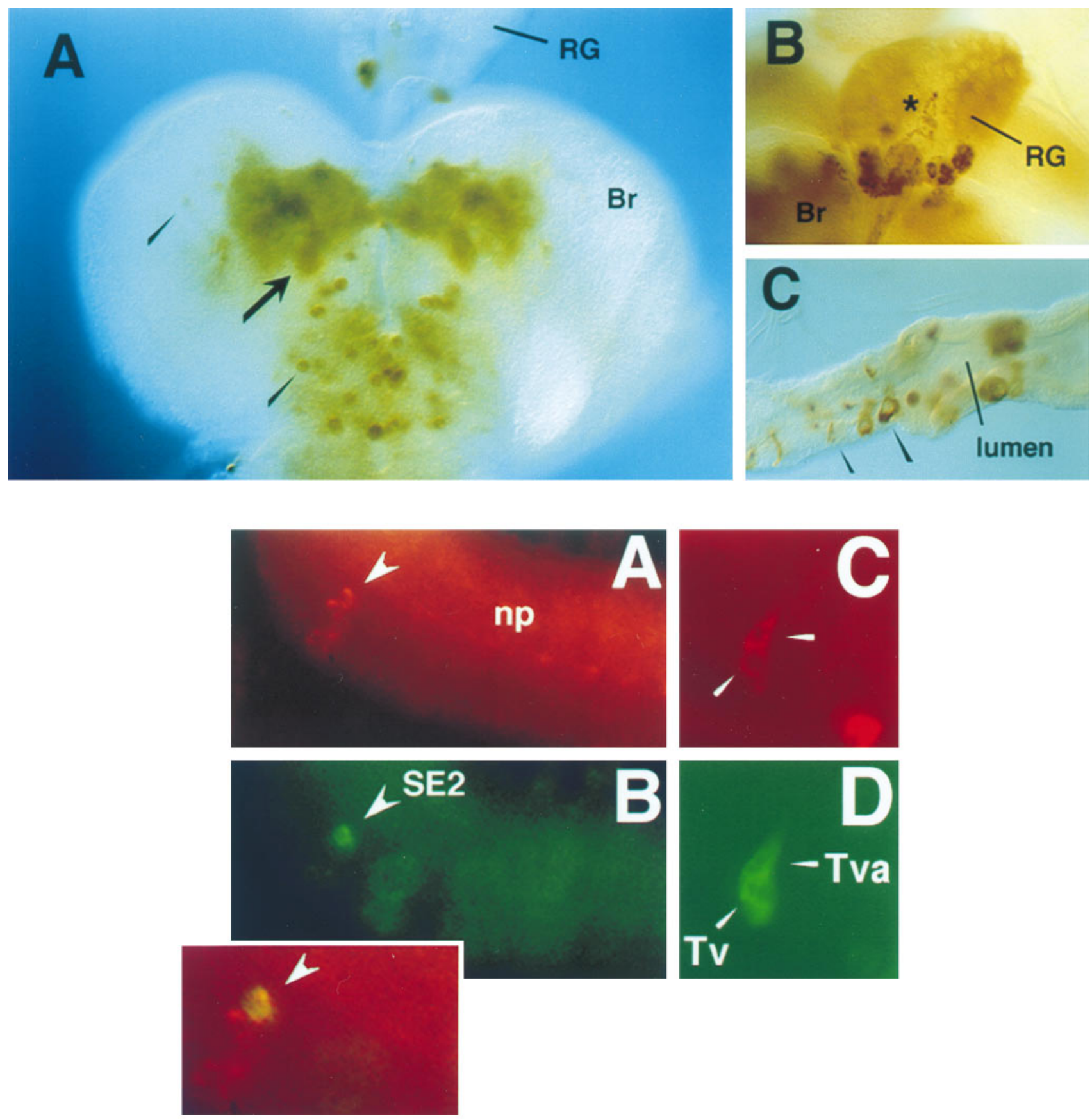

Figure 12. Top. Whole-mount tissue staining using an affinity-purified anti-PHM antibody in the CNS and in non-neural tissues. $A$, The third instar larval CNS exhibits distributed cell body and neuropilar staining. This view displays only a portion of the CNS; it is a ventral focal plane that includes the brain lobes and the most rostral portions of the ventral ganglion. Arrowheads mark stained cell bodies, and the arrow indicates regions of stained neuropil. Note the symmetry in both stained features. The low level of anti-PHM antibody staining that was displayed by the majority of neurons at this stage was very similar to the level of background staining observed with preimmune serum. $B r$, Brain lobe; $R G$, Ring Gland. $B$, High magnification view of the larval Ring Gland from another specimen of comparable age to show inclusion of stained endocrine cell bodies within the corpora cardiaca; asterisk indicates stained axons and terminals of brain neurosecretory neurons projecting within the $R G$. The cell bodies of the immunoreactive brain neurons that project to the $R G$ are not visible in this panel. $C$, Image of a portion of the larval midgut to indicate the amount and diversity of immunoreactive cells that appear in the midgut epithelium. Arrowheads indicate divergent immunoreactive cell morphologies. lumen, Midgut lumen.

Figure 13. Bottom. Double-immunofluorescent staining of the larval nervous system from the pWF3-y FMRFamide- $\beta$-gal reporter stock to analyze the identity of PHM-positive neurons. The red channel displays anti-PHM staining $(A$ and $C)$; the green channel displays anti-lacZ staining, which is indicative of $d F M R F a m i d e(B$ and $D$ ). The inset displays a computer overlay of the images in $A$ and $B$. The interneuronal $S E 2$ neurons express FMRFamide-lacZ and are among a group of strong PHM-positive cells ( $A$ and $B$; only one of the two SE2 neurons in the CNS is seen in this focal plane). Some of the strong PHM-positive neurons in the lateral thoracic neuromeres correspond to the $T v$ group of FMRFamide neurons: $T v$ and $T v a$ are identified neuroendocrine neurons that both express PHM immunoreactivity $(C$ and $D) . n p$, Neuropil. 
pendent revertants of the insertion have lost the lethality that previously was associated with that chromosome, suggesting that the lethality of the $\mathrm{P}[07623]$ chromosome maps to the insertion. The simplest explanation is that $P H M$ gene function is curtailed in this insertion background and that a critical function for this gene is revealed. These observations raise several questions regarding $\mathrm{dPHM}$ roles in vivo: when is $\mathrm{APHM}$ first expressed and how does its expression correlate with the death of the animals? Further, can peptide amidation still take place, and what are the cellular and molecular consequences of impairing $>90 \%$ of the neuropeptides deployed by the nervous system? Defining the roles of PHM in vivo using genetic and molecular methods will continue to provide important insights into the processes of neuropeptide biosynthesis and also should shed light on the evolution of the $P H M / P A L$ genes.

\section{REFERENCES}

Amy CM, Williams-Ahlf B, Naggert J, Smith S (1992) Intron-exon organization of the gene for the multifunctional animal fatty acid synthase. Proc Natl Acad Sci USA 89:1105-1108.

Ashburner M (1989) Drosophila: a laboratory manual. Cold Spring Harbor, NY: Cold Spring Harbor Laboratory.

Chiang C, Patel NH, Young KE, Beachy PA (1994) The novel homeodomain gene buttonless specifies differentiation and axonal guidance functions of Drosophila dorsal median cells. Development (Camb) 120:3581-3593.

De Bie I, Savaria D, Roebroek AJM, Day R, Lazure C, Van de Ven WJM, Seidah NG (1995) Processing specificity and biosynthesis of the Drosophila melanogaster convertases dfurin1, dfurin-CRR, dfurin1-X, and dfurin2. J Biol Chem 270:1020-1028.

Eipper BA, Perkins SN, Husten EJ, Johnson RC, Keutmann HT, Mains RE (1991) Peptidyl- $\alpha$-hydroxyglycine $\alpha$-amidating lyase. Purification, characterization, and expression. J Biol Chem 266:7827-7833.

Eipper BA, Stoffers DA, Mains RE (1992) The biosynthesis of neuropeptides: peptide $\alpha$-amidation. Annu Rev Neurosci 15:57-85.

Eipper BA, Milgram SL, Husten EJ, Yun HY, Mains RE (1993) Peptidylglycine $\alpha$-amidating mono-oxygenase: a multifunctional protein with catalytic, processing, and routing domains. Protein Sci 2:489-497.

Eipper BA, Quon ASW, Mains RE, Boswell JS, Blackburn NJ (1995) The catalytic core of peptidylglycine $\alpha$-hydroxylating mono-oxygenase: investigation by site-directed mutagenesis, $\mathrm{Cu}$ x-ray absorption spectroscopy, and electron paramagnetic resonance. Biochemistry 34:2857-2865.

Feany MB, Quinn WG (1995) A neuropeptide gene defined by the Drosophila memory mutant amnesiac. Science 268:869-873.

Grimmelikhuijzen CJ, Westfall JA (1995) The nervous system of cnidarians. EXS 72:7-24.

Hand TA, Mains RE, Eipper BA (1997) Identification of the promoter for the gene encoding the bifunctional enzyme, peptidylglycine $\alpha$-amidating mono-oxygenase. DNA Cell Biol, in press.

Hayflick JS, Wolfgang WJ, Forte MA, Thomas G (1992) A unique Kex2-like endoprotease from Drosophila melanogaster is expressed in the central nervous system during early embryogenesis. J Neurosci 12:705-717.

Husten EJ, Eipper BA (1991) The membrane-bound bifunctional peptidylglycine $\alpha$-amidating mono-oxygenase protein. Exploration of its domain structure through limited proteolysis. J Biol Chem 266:17004-17010.

Husten EJ, Tausk FA, Keutmann HT, Eipper BA (1993) Use of endoproteases to identify catalytic domains, linker regions, and functional interactions in soluble PAM. J Biol Chem 268:9709-9717.

Iwasaki Y, Shimoi H, Saiki H, Nishikawa Y (1993) Tissue-specific molecular diversity of amidating enzymes (peptidylglycine alphahydroxylating mono-oxygenase) and peptidylhydroxyglycine $\mathrm{N}-\mathrm{C}$ lyase) in Xenopus laevis. Eur J Biochem 214:811-818.

Katapodis AG, Ping D, Smith CE, May SW (1991) Functional and structural characterization of peptidylamidoglycolate lyase, the enzyme catalyzing the second step in peptide amidation. Biochemistry 30:6189-6194.

Kolhekar AS, Mains RE, Eipper BA (1997) Peptidylglycine $\alpha$-amidating mono-oxygenase (PAM): an ascorbate requiring enzyme. Methods Enzymol, in press.
Lindberg I, Zhou Y (1995) Overexpression of neuropeptide precursors and processing enzymes. Methods Neurosci 23:94-108.

Monastirioti M, Linn Jr CE, White K (1996) Characterization of Drosophila tyramine- $\beta$-hydoxylase gene and isolation of mutant flies lacking octopamine. J Neurosci 16:3900-3911.

Nambu JR, Murphy-Erdosh C, Andrews PC, Feistner G, Scheller RH (1988) Isolation and characterization of a Drosophila neuropeptide gene. Neuron 1:55-61.

Nassel DR (1994) Neuropeptides, multifunctional messengers in the nervous system of insects. Verh Dtsch Zool Ges 87:59-81.

Nassel DR (1996) Neuropeptides, amines, and amino acids in an elementary insect ganglion: functional and chemical anatomy of the unfused abdominal ganglion. Prog Neurobiol 48:325-420.

Nassel DR, Bayraktaroglou E, Dirckson H (1994) Neuropeptides in neurosecretory and efferent neural systems of insect thoracic and abdominal ganglia. Zool Sci 11:15-31.

Nichols R (1992a) Isolation and structural characterization of Drosophila TDVDHVFLRFamide and FMRFamide-containing peptides. J Mol Neurosci 3:213-218.

Nichols R (1992b) Isolation and expression of the Drosophila drosulfakinin neural peptide gene product. Mol Cell Neurosci 3:342-347.

Nichols R, Schneuwly SA, Dixon JE (1988) Identification and characterization of a Drosophila homologue to the vertebrate neuropeptide cholecystokinin. J Biol Chem 263:12167-12170.

O'Hare K, Rubin GM (1983) Structures of P transposable elements and their sites of insertion and excision in the Drosophila melanogaster genome. Cell 34:25-35.

Ouafik L, Stoffers DA, Campbell TA, Johnson RC, Bloomquist BT, Mains RE, Eipper BA (1992) The multifunctional peptidylglycine $\alpha$-amidating mono-oxygenase gene: exon/intron organization of catalytic, processing, and routing domains. Mol Endocrinol 6:1571-1584.

Perkins SN, Husten EJ, Eipper BE (1990) The 108 kDa peptidylglycine $\alpha$-amidating mono-oxygenase precursor contains two separable enzymatic activities involved in peptide amidation. Biochem Biophys Res Commun 171:926-932.

Restifo LL, White K (1990) Molecular and genetic approaches to neurotransmitter and neuromodulator systems in Drosophila. Adv Insect Physiol 22:115-219.

Rhodes CH, Xu RY, Angeletti RH (1990) Peptidylglycine $\alpha$-amidating mono-oxygenase (PAM) in Schwann cells and glia as well as neurons. J Histochem Cytochem 38:1301-1311.

Roebroek AJM, Pauli IGL, Zhang Y, Van de Ven WJM (1991) cDNA sequence of a Drosophila melanogaster gene, Dfur1, encoding a protein related to the subtilisin-like proprotein processing enzyme. FEBS Lett 289:133-137.

Rouille Y, Duguay SJ, Lund K, Furuta M, Gong Q, Lipkind G, Oliva AA, Chan SJ, Steiner DF (1995) Proteolytic processing mechanisms in the biosynthesis of neuroendocrine peptides. Front Neuroendocrinol 16:322-361.

Sambrook J, Fritsch EF, Maniatis T (1989) Molecular cloning, 2nd Ed. Cold Spring Harbor, NY: Cold Spring Harbor Laboratory.

Schafer MK, Stoffers DA, Eipper BA, Watson SJ (1992) Expression of peptidylglycine $\alpha$-amidating mono-oxygenase (EC 1.14.17.3) in the rat central nervous system. J Neurosci 12:222-234.

Schaffer MH, Noyes BE, Slaughter CA, Thorne GC, Gaskell SJ (1990) The fruitfly Drosophila melanogaster contains a novel charged adipokinetic hormone family peptide. Biochemistry 269:315-320.

Schneider LE, Taghert PH (1988) Isolation and characterization of a Drosophila gene encoding multiple neuropeptides related to FMRFamide (Phe-Met-Arg-Phe-NH $\mathrm{NH}_{2}$. Proc Natl Acad Sci USA 85:1993-1997.

Schneider LE, Roberts MS, Taghert PH (1993) Cell type-specific transcriptional regulation of the Drosophila FMRFamide neuropeptide gene. Neuron 10:279-291.

Seidah NG (1995) Molecular strategies for identifying processing enzymes. Methods Neurosci 23:3-15.

Settle SH, Green MM, Burtis KC (1995) The silver gene of Drosophila melanogaster encodes multiple carboxypeptidases similar to mammalian prohormone-processing enzymes. Proc Natl Acad Sci USA 92:94709474.

Sossin WS, Fisher JM, Scheller RH (1989) Cellular and molecular biology of neuropeptide processing and packaging. Neuron 2:1407-1417.

Southan C, Kruse LI (1989) Sequence similarity between DBH and 
PAM: evidence for a conserved catalytic domain. FEBS Lett 255:116-120.

Stewart LC, Klinman JP (1988) Dopamine beta-hydroxylase of adrenal chromaffin granules: structure and function. Annu Rev Biochem 57:551-592

Taghert PH, Schneider LE (1990) Interspecific comparison of the FMRFamide neuropeptide gene between two species of Drosophila. J Neurosci 10:1929-1939.

Tajima M, Iida T, Yoshida B, Komatsu K, Namba R, Yanagi M, Noguchi M, Okamoto H (1990) The reaction product of peptidylglycine $\alpha$-amidating enzyme is a hydroxyl derivative at $\alpha$-carbon of the carboxyl terminal glycine. J Biol Chem 265:9602-9605.

Tublitz NJ, Bate CM, Davies SA, Dow JAT, Maddrell SHP (1994) A neuronal function for the midline mesodermal cells in Drosophila. Soc Neurosci Abstr 20:533.

Veenstra J (1994) Isolation and structure of the Drosophila corazonin gene. Biochem Biophys Res Commun 204:292-296.

Wang N, Southan C, DeWolf Jr WE, Wells TNC, Kruse LI, Leatherbarrow RJ (1990) Bovine dopamine beta-hydroxylase, primary structure determined by cDNA cloning and amino acid sequencing. Biochemistry 29:6466-6474.

Zabriskie TM, Klinge M, Szymanski CM, Cheng H, Vederas JC (1994) Peptide amidation in an invertebrate: purification, characterization, and inhibition of peptidylglycine alpha-hydroxylating mono-oxygenase from the heads of honeybees (Apis mellifera). Arch Insect Biochem Physiol 26:27-48. 